\title{
Selective Laser Trabeculoplasty: An Overview
}

\author{
${ }^{1}$ Bhaskar Jha, ${ }^{2}$ Shibal Bhartiya, ${ }^{3}$ Reetika Sharma, ${ }^{4}$ Tarun Arora, ${ }^{5}$ Tanuj Dada
}

\begin{abstract}
Given the obvious quality of life concerns with medical and surgical lowering of intraocular pressure (IOP), lasers have received considerable attention as a therapeutic modality for glaucoma.

Selective laser trabeculoplasty (SLT) is increasingly being used in clinical practice as both the primary procedure and as an adjunct to medical and surgical therapy. Preliminary published evidence suggests that SLT is an effective, compliance-free, repeatable and safe therapeutic modality having only minor, transient, self-limiting or easily controlled side effects with no sequelae.

This review attempts a broad overview of the current knowledge of its mechanism, efficacy, indications and limitations, point out the knowledge lacunae that still exist with respect to this highly promising technology which has captured the attention of glaucoma surgeons all over the world.
\end{abstract}

Keywords: Selective laser trabeculoplasty, Lasers in glaucoma, Argon laser trabeculoplasty, Compliance and glaucoma.

How to cite this article: Jha B, Bhartiya S, Sharma R, Arora T, Dada T. Selective Laser Trabeculoplasty: An Overview. J Current Glau Prac 2012;6(2):79-90.

\section{Source of support: Nil}

Conflict of interest: None declared

\section{INTRODUCTION}

Glaucoma is a progressive optic neuropathy and may lead to irreversible blindness. It is one of the leading causes of blindness, worldwide. ${ }^{1}$ The only known modifiable risk factor for disease onset and progression is intraocular pressure (IOP), the reduction of which may slow down progression in glaucoma.

Given the obvious quality of life concerns with medical and surgical lowering of IOP, lasers have received considerable attention as a therapeutic modality for glaucoma.

Laser application to the trabecular meshwork (TM) or laser trabeculoplasty (LTP) has been used since the early 1970s. It was first described in 1973 by Worthen and Wickham, ${ }^{2}$ using an argon laser to perform trabeculoplasty, and by $\mathrm{Krasnov}^{3}$ using a Q-switched ruby laser to perform goniopuncture or laser puncture. It was not until 1979 that Wise and Witter ${ }^{4}$ described a modified technique to perform argon laser trabeculoplasty (ALT), which subsequently gained acceptance as a therapeutic option of open-angle glaucoma $(\mathrm{OAG})$. Since then, it has been seen that trabeculoplasty can also be performed with Krypton lasers, ${ }^{5}$ continuous wave neodymium lasers ${ }^{6}$ and diode lasers ${ }^{7}$ with results similar to those seen with ALT.
In the glaucoma laser trial follow-up study, after 7 years of follow-up, patients with ALT had lower IOP than patients on medical treatment (the glaucoma laser trial research group 1990, 1995). ${ }^{8,9}$ LTP appears to be less costly than current medical treatment. ${ }^{10}$ LTP can lower IOP without relying on patient compliance with medications, which has been repeatedly shown to be a common problem. ${ }^{11-14}$

By replacing or decreasing the need for topical medications, LTP can reduce systemic side effects, such as cardiorespiratory depression ${ }^{15}$ and local side effects, such as allergy, ${ }^{16}$ chronic inflammation ${ }^{17,18}$ which may decrease the success rate of future filtration surgery ${ }^{19}$ and cosmetic changes. $^{20}$

Selective laser trabeculoplasty (SLT) was listed by the FDA in 2002 as a procedure separate from ALT. SLT is the delivery of laser energy to TM using parameters such that the result is the selective absorption of energy by pigmented cells, sparing adjacent cells and tissues from thermal damage. Although the mechanism of its action is even less well understood than that of ALT, it provides IOP reduction that is similar in magnitude and duration to that obtained with ALT, is associated with very few complications and offers several other potential advantages over ALT.

This review attempts a broad overview of the current knowledge of its mechanism, efficacy, indications and limitations point out the knowledge lacunae that still exist with respect to this highly promising technology which has captured the attention of glaucoma surgeons all over the world.

\section{MECHANISM OF ACTION OF SLT}

This procedure is called SLT because there is a selective effect on melanotic elements associated with the meshwork. SLT is possible because pigmented TM cells exhibit greater optical absorbance of the applied laser energy than the cells that surround them. ${ }^{21}$ Histologic studies have shown that there is less coagulative damage after SLT and less structural change of the meshwork. ${ }^{22}$ A short burst of laser energy heats and thermally damages pigmented TM cells before neighboring cells have a chance to absorb enough laser energy to incur any thermal damage. ${ }^{23}$ Latina and Park have demonstrated selective killing of the cultured, pigmented TM cells over nonpigmented TM cells using the principles of selective photothermolysis (SP). ${ }^{23-26}$ The pigmented TM endothelial cells have melanin as the intracellular pigment and, thus, it is possible to confine the damage to these cells 
using the principles of SP. This approach relies on selective targeting of the pigmented TM cells using single laser pulses of short pulse duration and low fluencies (energy/area), to generate and confine heat to the pigmented cells. ${ }^{23}$ One important characteristic of the principle of SP is that multiple targeting of only the pigmented TM cells can be affected simultaneously without using focusing to achieve specificity. Using a short laser pulse confines the thermal damage to the cell containing the pigment target, if the duration of the laser pulse is equal to or less than the thermal relaxation time of the intracellular pigment. ${ }^{23,27}$ The thermal relaxation time of melanin is approximately 1 millisecond and the pulse duration of SLT laser is 3 nanosecond, and this essentially prevents thermal dissipation to surrounding tissues. ${ }^{27}$ The large spot size in SLT $(400 \mathrm{~mm})$ versus the small spot size in ALT $(50 \mathrm{~mm})$ also ensures that low fluences can be maintained, which is necessary to prevent collateral thermal damage to the surrounding tissues. ${ }^{23}$ Although melanin has a broad absorption spectrum, it has been shown that for the destruction of melanin-containing cells, a wavelength of about $504 \mathrm{~nm}$ seems optimal. ${ }^{23,28}$ The mechanism of action of SLT has been explained by biological theory which suggests that trabecular photocoagulation stimulates some biologic response that could contribute to eventual reduction in the IOP. ${ }^{29}$ Although ALT destroys both the pigmented and the nonpigmented TM endothelial cells at the burn site, it has been shown in studies using human TM maintained in organ culture model that, after ALT, the trabecular cells in the region near the Schwalbe line are stimulated to divide. ${ }^{30,31}$ This cell division seemed to occur not only in the half treated with laser photocoagulation but also in the opposite $180^{\circ}$ nonlasered TM segments. No stimulation of the corneal endothelial cells or trabecular overgrowth by these cells was noted in these studies. It has been suggested that perhaps these cells in the anterior nonfiltering portion of the TM are multipotent cells, and that injury to the trabeculum from laser trabeculoplasty stimulates them to divide, to migrate and repopulate the TM beams at the burn sites, to fabricate a new extracellular matrix or phagocytize. ${ }^{32}$ Although the precise barriers to aqueous humor outflow are not understood, it has been suggested that the proteoglycan components of the extracellular matrix are significant contributors. ${ }^{33,34}$ It has been shown that argon laser photocoagulation of the TM causes alteration in the turnover or synthesis of trabecular extracellular matrix and this might result in an improvement in the aqueous outflow. ${ }^{35}$ The stimulation of the trabecular cells with an increase in their phagocytic activity, after the ALT, might also help in cleaning the TM of any 'clogging' debris. ${ }^{36}$

\section{Predictive Factors of SLT Success}

The predictors of success following SLT have been studied in various population, and the results obtained have been found to be similar, though not identical. This may be attributed to the fact that the population studied varied in terms of race, age, severity of glaucoma and also SLT treatment protocols (Table 1).

Gracner et a ${ }^{37}$ reported a negative correlation between successful SLT and the grade of TM pigmentation and

Table 1: Predictors of success following SLT

\begin{tabular}{|c|c|c|c|c|c|c|}
\hline Study & Population & Treatment & Follow-up duration & Negative correlation & Positive correlation & $\begin{array}{l}\text { No significant } \\
\text { relation }\end{array}$ \\
\hline Gracner et $\mathrm{al}^{37}$ & & & & $\begin{array}{l}\text { Diabetes, trabecular } \\
\text { meshwork } \\
\text { pigmentation }\end{array}$ & $\begin{array}{l}\text { IOP elevation } \\
\text { before laser } \\
\text { treatment }\end{array}$ & $\begin{array}{l}\text { Baseline IOP, age, } \\
\text { sex, hypertension, } \\
\text { family history of } \\
\text { glaucoma, } \\
\text { previous anterior } \\
\text { segment surgery, } \\
\text { laser energy } \\
\text { used and local } \\
\text { antiglaucoma } \\
\text { therapy }\end{array}$ \\
\hline Hodge et $\mathrm{al}^{38}$ & & & & & Baseline IOP & $\begin{array}{l}\text { Age, sex, other } \\
\text { glaucoma risk } \\
\text { factors, type of } \\
\text { open angle } \\
\text { glaucoma or by } \\
\text { degree of } \\
\text { trabecular } \\
\text { meshwork } \\
\text { pigmentation }\end{array}$ \\
\hline Mao et $\mathrm{al}^{39}$ & & & & $\begin{array}{l}\text { IOP before } \\
\text { SLT treatment }\end{array}$ & $\begin{array}{l}\text { IOP before } \\
\text { SLT treatment }\end{array}$ & $\begin{array}{l}\text { Similar } \\
\text { correlation }\end{array}$ \\
\hline
\end{tabular}


diabetes. They did not find any significant correlations between successful SLT and baseline IOP, age, gender, hypertension, family history of glaucoma, previous anterior segment surgery, laser energy used or local antiglaucoma therapy. They found that SLT efficacy is positively associated with IOP elevation before laser treatment. This result is consistent with Hodge et $\mathrm{al}^{38}$ who reported that SLT success was significantly predicted by baseline IOP but not by age, sex, other glaucoma risk factors, type of open angle glaucoma or by degree of TM pigmentation.

Mao et $\mathrm{al}^{39}$ reported a positive association between laser efficacy and IOP before SLT treatment. Marcelo et $\mathrm{al}^{40}$ conducted a retrospective review of reports of 120 eyes which had SLT, and found a significant correlation between successful SLT and age, baseline IOP and amount of laser energy delivered.

\section{Clinical Results of SLT}

Preliminary clinical results with SLT were reported by Latina et $\mathrm{al}^{41}$ in 1998 in a study of 53 eyes of patients with open angle glaucoma (OAG) and uncontrolled IOP on maximum tolerated medical therapy (MTMT) or after previous ALT. Nearly all eyes had primary OAG (POAG). The nasal $180^{\circ}$ were treated. Follow-up ranged from 4 to 26 weeks, with 44 eyes completing 26 weeks of followup. IOP was reduced, on average by $4.1 \mathrm{~mm} \mathrm{Hg}(16.3 \%)$ at 1 week and by $4.6 \mathrm{~mm} \mathrm{Hg}(18.7 \%)$ at 26 weeks. IOP in the untreated eye at 26 weeks was reduced by $2.1 \mathrm{~mm}$ $\mathrm{Hg}(9.7 \%)$. At 26 weeks, IOP had decreased by more than $3 \mathrm{~mm} \mathrm{Hg}$ and by a mean of $5.9 \mathrm{~mm} \mathrm{Hg}(23.8 \%)$ in 32 eyes. Eyes were not treated with glaucoma medications immediately prior to the procedure, and IOP elevation of greater than $5 \mathrm{~mm} \mathrm{Hg}$ was observed in 13 eyes (25\%). In all cases, this was seen within 2 hours and resolved with topical antihypertensive medications within 24 hours. Mildto-moderate anterior chamber reaction was observed in 44 eyes (83\%) one hour after the procedure, and resolved completely within 5 days in all cases with routine postoperative treatment of prednisolone acetate $1 \%$ four times daily for 5 days. Except for transient pain and blurred vision in $15 \%$ of cases and redness in $9 \%$, no other complications were reported.

Lanzetta et $\mathrm{al}^{42}$ reported that $360^{\circ}$ SLT could achieve clinically significant IOP reduction in eight eyes with high IOP that was uncontrolled with MTMT, even after previous ALT or trabeculectomy. Lower IOP that was observed after 24 hours had remained stable through 6 weeks. One eye had an immediate postoperative IOP rise of $10 \mathrm{~mm} \mathrm{Hg}$, which dissipated quickly.
Chen et $\mathrm{al}^{43}$ prospectively compared SLT of $90^{\circ}$ and $180^{\circ}$ in two groups of 32 patients with ocular hypertension (OHTN) or primary, pigmentary or exfoliative OAG. Some eyes had previously undergone ALT. At 7 months follow-up, 13 of 32 eyes and 15 of 32 eyes in the two groups respectively, required retreatment or trabeculectomy. Excluding these eyes, mean IOP was reduced from 25.44-1.41 to 18.43-1.38 $\mathrm{mm} \mathrm{Hg}$ and from 26.06-1.73 to $19.90-1.59 \mathrm{~mm} \mathrm{Hg}$ by each treatment respectively, with the difference not statistically different. No acute or delayed complications were reported. The degree of trabecular pigmentation was significantly related to the degree of IOP reduction at 7 months but not at 1 or 4 months. Throughout follow-up, neither the presence of exfoliation or previous ALT treatment was significantly related to IOP reduction throughout the follow-up.

A study by Melamed ${ }^{44}$ et al suggests that SLT may be a safe, noninvasive, and effective treatment modality in $\mathrm{OAG}$ as a primary treatment instead of topical medications or ALT. Of 31 patients with POAG or OHT, 45 eyes underwent SLT as primary treatment. The mean \pm SD baseline IOP for all eyes was $25.5 \pm 2.5 \mathrm{~mm} \mathrm{Hg}$ and the final IOP was $17.9 \pm 2.8 \mathrm{~mm} \mathrm{Hg}$, a decrease of $30 \%$. Only three eyes required topical ocular hypotensive medications to reduce IOP post-SLT. Most patients (40 eyes or $89 \%$ ) had an IOP decrease than $5 \mathrm{~mm} \mathrm{Hg}$ at the end of the follow-up period (18 months).

The results of the main studies are summarized in Table 2.

\section{COMPARING MEDICAL MANAGEMENT AND SLT}

L Jay Katz et $\mathrm{al}^{49}$ conducted a prospective randomized clinical trial to compare outcomes SLT of with drug therapy for glaucoma patients in 69 patients ( 127 eyes) with open angle glaucoma or ocular hypertension. Target IOP was determined using the collaborative initial glaucoma treatment study formula. Patients were treated with SLT (100 applications $360^{\circ}$ ) or medical therapy (prostaglandin analog). Six visits over 1 year followed initial treatment. Twenty-nine patients were in the SLT group, 25 patients in the medical group. Baseline mean IOP for all eyes was $24.5 \mathrm{~mm} \mathrm{Hg}$ in the SLT group, $24.7 \mathrm{~mm} \mathrm{Hg}$ in the medical group. Mean IOP (both eyes) at last follow-up was $18.2 \mathrm{~mm} \mathrm{Hg}$ (6.3 $\mathrm{mm} \mathrm{Hg}$ reduction) in the SLT arm, $17.7 \mathrm{~mm} \mathrm{Hg}$ (7.0 mm Hg reduction) in the medical arm. By last follow-up, $11 \%$ of eyes received additional SLT, $27 \%$ required additional medication. There was no statistically significant difference between the SLT and medication groups. 
Table 2: Clinical results of SLT

\begin{tabular}{|c|c|c|c|c|c|c|c|c|}
\hline Study & Population & Treatment & $\begin{array}{l}\text { Baseline } \\
\mathrm{IOP}\end{array}$ & Follow-up & IOP reduction & $\begin{array}{l}\text { Definition of } \\
\text { success }\end{array}$ & $\begin{array}{l}\text { Response } \\
\text { rate }\end{array}$ & Comments \\
\hline Latina et al ${ }^{41}$ & $\begin{array}{l}53 \text { eyes with } \\
\text { OAG on } \\
\text { MTMT with } \\
\text { ALT; } 44 \text { eyes } \\
26 \text { weeks } \\
\text { follow-up } \\
\text { was done }\end{array}$ & $\begin{array}{l}\text { SLT nasal } \\
180^{\circ}\end{array}$ & 24.6 & 26 weeks & $\begin{array}{l}4.6 \mathrm{~mm} \mathrm{Hg} \\
(18.7 \%)\end{array}$ & $\begin{array}{l}\text { IOP reduction } \\
>3 \mathrm{~mm} \mathrm{Hg}\end{array}$ & $73 \%$ & \\
\hline $\begin{array}{l}\text { Lanzetta } \\
\text { et al }{ }^{42}\end{array}$ & $\begin{array}{l}8 \text { eyes of } \\
6 \text { patients } \\
\text { with POAG } \\
\text { on MTMT } \\
\text { some with } \\
\text { previous ALT }\end{array}$ & $360^{\circ} \mathrm{SLT}$ & 26.6 & 6 weeks & $\begin{array}{l}10.6 \pm 5.5 \\
\mathrm{~mm} \mathrm{Hg}(40 \%)\end{array}$ & NA & NA & NA \\
\hline Kajiya et al ${ }^{47}$ & $\begin{array}{l}17 \text { eyes of } \\
10 \text { patients } \\
\text { with POAG } \\
1 \text { eye with } \\
\text { XFG }\end{array}$ & $180^{\circ} \mathrm{SLT}$ & 22.8 & 6 months & $6.7 \mathrm{~mm} \mathrm{Hg}$ & NA & NA & \\
\hline Chen et al ${ }^{43}$ & $\begin{array}{l}2 \text { groups of } \\
32 \text { patients } \\
\text { with or OAG } \\
\text { some with } \\
\text { previous ALT }\end{array}$ & $180^{\circ}$ & $\begin{array}{l}26.06 \pm \\
1.73 \mathrm{~mm} \mathrm{Hg}\end{array}$ & 7 months & $6.16 \mathrm{~mm} \mathrm{Hg}$ & $\begin{array}{l}\text { IOP con- } \\
\text { trolled without } \\
\text { retreatment } \\
\text { or trabeculec- } \\
\text { tomy } \\
\text { IOP reduction }\end{array}$ & $59 \%$ & $\begin{array}{l}\text { IOP reduc- } \\
\text { tion positively } \\
\text { correlated with } \\
\text { trabecular } \\
\text { meshwork } \\
\text { pigmentation }\end{array}$ \\
\hline Johnson et al ${ }^{44}$ & $\begin{array}{l}132 \text { eyes } \\
\text { (95 patients) } \\
\text { with OAG }\end{array}$ & $360^{\circ} \mathrm{SLT}$ & 20.9 & 3 months & $\begin{array}{l}3.74-4.58 \\
\mathrm{~mm} \mathrm{Hg} \\
(12.4 \%)\end{array}$ & $\begin{array}{l}\$ 30 \% \\
\text { IOP reduction }\end{array}$ & $24 \%$ & \\
\hline Cvenkel $^{45}$ & $\begin{array}{l}44 \text { eyes of } 31 \\
\text { patients with } \\
\text { medically } \\
\text { controlled } \\
\text { OAG }\end{array}$ & $\begin{array}{l}\text { SLT inferior } \\
180^{\circ}\end{array}$ & $\begin{array}{l}25.57 \\
\text { (range } \\
22-34 \text { ) }\end{array}$ & $\begin{array}{l}12 \text { months } \\
\text { (40 eyes) }\end{array}$ & $\begin{array}{l}4.8 \mathrm{~mm} \mathrm{Hg} \\
(18.6 \%) \\
\text { at } 6 \text { months } \\
4.4 \mathrm{~mm} \mathrm{Hg} \\
(17.1 \%) \text { at } \\
12 \text { months }\end{array}$ & $\$ 3 \mathrm{~mm} \mathrm{Hg}$ & $\begin{array}{l}66 \% \text { at } 3 \\
\text { months }\end{array}$ & \\
\hline Gracner $^{46}$ & $\begin{array}{l}50 \text { eyes with } \\
\text { OAG }\end{array}$ & $180^{\circ} \mathrm{SLT}$ & 22.48 & 6 months & $\begin{array}{l}5.06 \pm 2.37 \\
\mathrm{~mm} \mathrm{Hg}\end{array}$ & $\begin{array}{l}>3 \mathrm{~mm} \mathrm{Hg} \\
60 \%\end{array}$ & $88 \%$ & \\
\hline Hodge et $\mathrm{al}^{48}$ & $\begin{array}{l}72 \text { patients } \\
\text { with OAG on } \\
\text { MTMT }\end{array}$ & $\begin{array}{l}180^{\circ} \mathrm{SLT} \\
23.8 \pm 4.88\end{array}$ & 12 months & $5.8 \mathrm{~mm} \mathrm{Hg}$ & $\begin{array}{l}\text { IOP reduction } \\
\text { of }>20 \% \text { after } \\
1 \text { year }\end{array}$ & 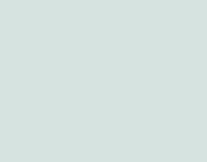 & & $\begin{array}{l}\text { IOP reduction } \\
\text { significantly } \\
\text { related to } \\
\text { baseline IOP }\end{array}$ \\
\hline Melamed et $\mathrm{al}^{44}$ & $\begin{array}{l}45 \text { eyes of } \\
31 \text { patients } \\
\text { with OAG or } \\
\text { OHTN } 37 \\
\text { newly diag- } \\
\text { nosed }\end{array}$ & $\begin{array}{l}\text { Nasal } 180^{\circ} \\
\text { SLT }\end{array}$ & $25.5 \pm \mathrm{SLT}$ & $\begin{array}{l}\text { Range of } \\
3-24\end{array}$ & $\begin{array}{l}7.7 \pm 3.5 \text { at } \\
\text { last follow-up }\end{array}$ & $\begin{array}{l}\text { IOP reduction } \\
>20 \%\end{array}$ & $96 \%$ & \\
\hline
\end{tabular}

Nagar et $\mathrm{al}^{50}$ conducted a prospective, randomized trial in which 167 eyes of 167 subjects received either 90, 180 or 360 degrees SLT or latanoprost $0.005 \%$ once daily at night. Successful treatment was defined as either $>20 \%$ or $>30 \%$ IOP reduction from baseline with no further IOP-lowering interventions. After a mean follow-up period of 10.3 months (range, 1-12 months), latanoprost therapy demonstrated superior success by both success definitions ( 90 and $78 \%$, respectively) compared with either $90^{\circ}$ (34 and $11 \%$, respectively) or $180^{\circ}$ SLT ( 65 and $48 \%$, respectively), and compared with $360^{\circ}$ SLT ( 82 and $59 \%$, equivalent IOP success respectively). 
Lai et al $^{51}$ conducted a prospective, randomized trial in which 29 newly diagnosed subjects with ocular hypertension or OAG underwent $360^{\circ}$ SLT in 1 eye and topical medical therapy (using 1 or more medications chosen by the investigator in a nonspecified fashion in the fellow eye). Mean IOP reduction after 5 years of follow-up was $8.6 \mathrm{~mm} \mathrm{Hg}$ (32.1\%) in SLT eyes and $8.7 \mathrm{~mm} \mathrm{Hg}(33.2 \%)$ in medically treated eyes $(\mathrm{p}=0.95)$; This included eight SLTtreated eyes $(27.6 \%)$ that required medications after SLT to maintain IOP below $21 \mathrm{~mm} \mathrm{Hg}$. Treatment failure (IOP $>21$ $\mathrm{mm} \mathrm{Hg}$ despite maximal medical therapy requiring filtering surgery) was observed in $17.2 \%$ of SLT eyes and $27.6 \%$ of medically treated eyes.

The results of the main clinical trials are summarized in Table 3.

\section{SLT Comparison to ALT}

Damji et $\mathrm{al}^{53}$ prospectively performed $180^{\circ}$ of SLT or ALT in a randomized fashion in 36 eyes of 34 patients with various forms of OAG. Some eyes had been previously treated with ALT. Average IOP and change in IOP did not differ statistically significantly between the two groups during 6 months of follow-up. At 6 months, IOP was reduced by 4.8 to $3.4 \mathrm{~mm} \mathrm{Hg}$ in the SLT group and 4.7 to $3.3 \mathrm{~mm} \mathrm{Hg}$ in the ALT group. Anterior chamber reaction was quantitated only 1 hour after the laser treatment, when there were, on average, statistically significantly more cells in eyes that had SLT and a similar amount of flare in both groups. These investigators subsequently extended their study to 176 eyes of 152 followed for 12 months. There was no statistically significant difference between IOP in the two groups at any time point from baseline to 12 months. At 12 months, IOP was reduced by a mean -5.86 to $6.1 \mathrm{~mm} \mathrm{Hg}$ in the SLT group and -6.0 to $4.8 \mathrm{~mm} \mathrm{Hg}$ in the ALT group. Importantly, it should be realized that the results of this study reflect a 'real-life' scenario more than a controlled study, because medication change, additional laser treatment and surgery were allowed during the study period and are partly responsible for the resulting IOP, in addition to the initial laser.

Juzych et $\mathrm{al}^{54}$ conducted a retrospective analysis to compare the longer-term outcomes of SLT with ALT. They reviewed the charts of all patients with uncontrolled chronic OAG who were treated with laser trabeculoplasty over a 6-month period by the same surgeon. Of these patients, 154 were treated with ALT and 41 with SLT patients. Preoperatively, patients in both groups had a similar IOP (23.9-2.6 in SLT group, 24.3-4.1 in ALT group) been using a similar average number of glaucoma medications (2.5-1.3 in SLT group, 2.5-1.2 in ALT group). Follow-up ranged from 3 to 60 months (mean, 32.5-15.9 months).
All eyes were pretreated with apraclonidine $1.0 \%$ and all underwent treatment of $180^{\circ}$ of the TM. When success was defined as IOP reduction of at least $3 \mathrm{~mm} \mathrm{Hg}$ without additional medications or surgery, it was recorded 1, 3 and 5 years after SLT in 68,46 and $32 \%$ of patients and, after ALT, in 54, 30, and 31\% respectively. Another criterion of success was defined as IOP reduction of 3 or more $\mathrm{mm} \mathrm{Hg}$ and $20 \%$ or more of the pretreatment IOP. At 1, 3, and 5 years, this was observed in 58, 38 and $31 \%$ of patients after SLT and in 46, 23 and 13\% after ALT respectively. The differences in success rates between SLT and ALT were not statistically significant.

Martinez-de-la-Casa et $\mathrm{al}^{55}$ prospectively performed SLT or ALT on the inferior $180^{\circ}$ in two groups, each of 20 eyes with POAG and no previous ALT. The IOP was similarly reduced in both groups at all time points. In the SLT group, IOP was lowered from 24 to $4.7 \mathrm{~mm} \mathrm{Hg}$ preoperatively to 22.1 to 3.7 and $18.6 \mathrm{~mm} \mathrm{Hg}(22.5 \%)$ at 1 week and 6 months respectively. In the ALT group, it was lowered from 23.6 to $3.8 \mathrm{~mm} \mathrm{Hg}$ preoperatively to 20.9 to 3.4 and 19-3.2 $\mathrm{mm} \mathrm{Hg}(19.5 \%)$ at 1 week and 6 months respectively. An IOP reduction of at least $3 \mathrm{~mm} \mathrm{Hg}$ was observed in $80 \%$ of the SLT-treated eyes (a mean percent decrease of $26.7 \%$ ) and in $85 \%$ of ALT-treated eyes (a mean decrease of $21.8 \%$ ).

The results of the main comparative studies are summarized in Table 4.

\section{HOW MUCH ANGLE IS TO BE TREATED?}

The principle of therapy by any modality is to apply the minimum amount of treatment necessary to achieve the maximum desired therapeutic with minimum adverse effects. As proved by many studies, SLT has a dose response effect.

In the study by Nagar et al, ${ }^{50} 90^{\circ}$ SLT treatment produced lower success rates than either 180 or $360^{\circ}$ SLT; the higher success rates with $360^{\circ}$ SLT compared with $180^{\circ}$ SLT did not reach the level of statistical significance ocular pain but not anterior chamber inflammation or the rate of IOP spikes was increased in eyes receiving 360 vs $90^{\circ}$ SLT.

Chen et $\mathrm{al}^{43}$ conducted a prospective randomized trial to compare two regimens of SLT. SLT with 25 laser spots on $90^{\circ}$ of TM and SLT with 50 laser spots on $180^{\circ}$ of TM in 64 subjects with uncontrolled OAG despite 2 or 3 IOP-lowering medications in a prospective. At 1, 4 and 7 months after treatment, mean IOP reduction (approximately 5-6 $\mathrm{mm} \mathrm{Hg}$ ) and the failure rate necessitating retreatment or incisional surgery (approximately 38\% at 4 months and $45 \%$ at 7 months) were identical between the two groups. No adverse events were reported in either group. 
Table 3: Results of the main clinical trials

\begin{tabular}{|c|c|c|c|c|c|c|c|}
\hline Study & Population & Treatment & Baseline IOP & Follow-up & IOP reduction & $\begin{array}{l}\text { Definition } \\
\text { success }\end{array}$ & $\begin{array}{l}\text { Response } \\
\text { rate }\end{array}$ \\
\hline \multirow[t]{11}{*}{ Nagar et al ${ }^{50}$} & \multirow{11}{*}{$\begin{array}{l}167 \text { patients } \\
\text { with OHTN or } \\
\text { OAG newly } \\
\text { diagnosed } \\
\text { or medically } \\
\text { controlled } \\
\text { after } \\
8 \text { washout }\end{array}$} & \multirow[t]{4}{*}{ Xalatan } & \multirow[t]{10}{*}{29.3} & \multirow[t]{11}{*}{$\begin{array}{l}\text { Mean } 10.3 \\
\text { months } \\
\text { (range 1-12) }\end{array}$} & \multirow[t]{9}{*}{ NA } & $\begin{array}{l}\text { IOP reduction } \\
\$ 20 \%\end{array}$ & $90 \%$ \\
\hline & & & & & & $\begin{array}{l}\text { IOP reduction } \\
\$ 30 \% \text { with no } \\
\text { additional } \\
\text { medications }\end{array}$ & $78 \%$ \\
\hline & & & & & & $\begin{array}{l}\text { IOP reduction } \\
\$ 20 \%\end{array}$ & \\
\hline & & & & & & $\begin{array}{l}\text { IOP reduction } \\
\$ 30 \% \text { with no } \\
\text { additional }\end{array}$ & $34 \%$ \\
\hline & & \multirow{2}{*}{$90^{\circ} \mathrm{SLT}$} & & & & medications & $11 \%$ \\
\hline & & & & & & $\begin{array}{l}\text { SLT IOP reduction } \\
\$ 20 \%\end{array}$ & \\
\hline & & \multirow[t]{3}{*}{$180^{\circ} \mathrm{SLT}$} & & & & $\begin{array}{l}\text { IOP reduction } \\
\$ 30 \% \text { with no } \\
\text { additional } \\
\text { medications }\end{array}$ & $65 \%$ \\
\hline & & & & & & $\begin{array}{l}\text { IOP reduction } \\
\$ 20 \%\end{array}$ & $48 \%$ \\
\hline & & & & & & $\begin{array}{l}\text { IOP reduction } \\
\$ 30 \% \text { with no } \\
\text { additional } \\
\text { medications }\end{array}$ & $82 \%$ \\
\hline & & \multirow{2}{*}{\multicolumn{2}{|c|}{$360^{\circ} \mathrm{SLT}$}} & & & & \\
\hline & & & & & & & $59 \%$ \\
\hline \multirow[t]{2}{*}{ Mcllraith et al ${ }^{52}$} & \multirow[t]{2}{*}{$\begin{array}{l}100 \text { eyes } \\
\text { with newly } \\
\text { diagnosed } \\
\text { early OAG } \\
\text { and OHTN }\end{array}$} & $\begin{array}{l}\text { Latanoprost } \\
\text { ( } 26 \text { eyes) }\end{array}$ & 24.6 & \multirow[t]{2}{*}{12 months } & $\begin{array}{l}7.7 \mathrm{~mm} \mathrm{Hg} \\
(30.6 \%)\end{array}$ & $\begin{array}{l}\text { IOP reduction } \\
\$ 30 \%\end{array}$ & $43 \%$ \\
\hline & & $\begin{array}{l}\text { SLT inferior } \\
180^{\circ} \mathrm{SLT} \\
(74 \text { eyes) }\end{array}$ & 26.0 & & $\begin{array}{l}8.3 \mathrm{~mm} \mathrm{Hg} \\
(31 \%)\end{array}$ & $\begin{array}{l}\text { IOP reduction } \\
\$ 30 \%\end{array}$ & $55 \%$ \\
\hline \multirow[t]{2}{*}{ Lai et al ${ }^{51}$} & \multirow{2}{*}{$\begin{array}{l}29 \text { Chinese } \\
\text { patients with } \\
\text { POAG or OHTN, } \\
\text { newly diagnosed }\end{array}$} & \multirow{2}{*}{$\begin{array}{l}360 \text { SLT } \\
\text { (fellow eye } \\
\text { treated with } \\
\text { medication) }\end{array}$} & \multirow[t]{2}{*}{$26.2-4.2$} & \multirow[t]{2}{*}{$\begin{array}{l}5 \text { years } \\
(82.8 \% \\
\text { completed })\end{array}$} & \multirow[t]{2}{*}{$\begin{array}{l}\text { 8.6-6.7 mm Hg } \\
(32.1 \%)\end{array}$} & \multirow{3}{*}{$\begin{array}{l}\text { IOP \#21 mm Hg } \\
\text { without medication } \\
\text { IOP \#21 mm Hg } \\
\text { on MTMT }\end{array}$} & \multirow[t]{2}{*}{$72 \%$} \\
\hline & & & & & & & \\
\hline Jay Katz et all ${ }^{49}$ & $\begin{array}{l}69 \text { patients } \\
\text { (127 eyes OAG } \\
\text { or OHTN were } \\
\text { randomized to } \\
\text { SLT or medical } \\
\text { therapy }\end{array}$ & $\begin{array}{l}\text { SLT ( } 100 \\
\text { applications } \\
360^{\circ} \text { ) or } \\
\text { medical therapy } \\
\text { (prostaglandin } \\
\text { analog) }\end{array}$ & $\begin{array}{l}24.5 \mathrm{~mm} \mathrm{Hg} \\
24.7 \mathrm{~mm} \mathrm{Hg} \\
\text { in the medical } \\
\text { group }\end{array}$ & $\begin{array}{l}9 \text { to } 12 \\
\text { months }\end{array}$ & $\begin{array}{l}(6.3 \mathrm{~mm} \mathrm{Hg} \\
\text { reduction) in } \\
\text { the } \mathrm{SLT} \text { arm, } \\
\text { ( } 7.0 \mathrm{~mm} \mathrm{Hg} \\
\text { reduction) in } \\
\text { the medical } \\
\text { arm }\end{array}$ & & \\
\hline
\end{tabular}

Song et a ${ }^{59}$ conducted a retrospective chart review of SLT treatments; 94 eyes from 94 patients were included. A majority $(83 / 92,90 \%)$ underwent $180^{\circ}$ SLT. Six months follow-up was done. SLT failure was defined in two ways: (1) IOP decrease, $3 \mathrm{~mm} \mathrm{Hg}$ (definition one), or (2) IOP decrease $20 \%$ (definition two), on two successive visits 4 weeks after SLT. According to definition one, a total of 64 eyes
(68\%) failed. According to definition two, a total of 70 eyes ( $75 \%)$ failed. By the end of the study (14.5 months), the failure rates were 86 and $92 \%$ by definitions one and two respectively, overall failure rates of 68 to $74 \%$.

Prasad et al ${ }^{60}$ conducted a retrospective chart review of patients to determine and compare the effect of 180 and $360^{\circ} \mathrm{SLT}$ treatment as a primary therapy on the intervisit 
Selective Laser Trabeculoplasty: An Overview

Table 4: SLT results over time

\begin{tabular}{|c|c|c|c|c|c|c|}
\hline Author & Type of study & $\begin{array}{l}\text { Number of } \\
\text { eyes }\end{array}$ & $\begin{array}{l}\text { Duration of } \\
\text { follow-up }\end{array}$ & $\begin{array}{l}\text { IOP reduction } \\
\text { in SLT }\end{array}$ & $\begin{array}{l}\text { IOP reduction } \\
\text { in } A L T\end{array}$ & $p$-value \\
\hline Damji et al ${ }^{53}$ & Prospective RCT & 36 & 6 months & $4.8 \mathrm{~mm} \mathrm{Hg}$ & $4.7 \mathrm{~mm} \mathrm{Hg}$ & 0.97 \\
\hline Damji et a $\left.\right|^{56}$ & Prospective RCT & 176 & 12 months & $5.86 \mathrm{~mm} \mathrm{Hg}$ & $6.04 \mathrm{~mm} \mathrm{Hg}$ & 0.846 \\
\hline Best et $\mathrm{al}^{57}$ & Prospective RCT & 165 & 12 months & $1.8 \mathrm{~mm} \mathrm{Hg}$ & $2.1 \mathrm{~mm} \mathrm{Hg}$ & NS \\
\hline Juzych et al ${ }^{54}$ & $\begin{array}{l}\text { Retrospective } \\
\text { case series }\end{array}$ & 195 & $\begin{array}{l}\text { 37.4 months (SLT), } \\
\text { 33.6 months (ALT) }\end{array}$ & & $\begin{array}{l}\text { Percent with } \\
\mathrm{Z} 3 \mathrm{~mm} \mathrm{Hg} \\
\text { reduction }\end{array}$ & $\begin{array}{l}\text { Without } \\
\text { further } \\
\text { therapy }\end{array}$ \\
\hline $\begin{array}{l}\text { Martinez-de-la- } \\
\text { Casa et al }{ }^{55}\end{array}$ & Prospective RCT & 40 & 6 months & $\begin{array}{l}18.6 \mathrm{~mm} \mathrm{Hg} \\
\text { (baseline } 24 \mathrm{~mm} \mathrm{Hg} \text { ) }\end{array}$ & $\begin{array}{l}19.0 \mathrm{~mm} \mathrm{Hg} \\
\text { (baseline } \\
23.6 \mathrm{~mm} \mathrm{Hg} \text { ) }\end{array}$ & 0.81 \\
\hline Popiela et $\mathrm{al}^{58}$ & Prospective RCT & 27 eyes & 3 months & $2.85 \mathrm{~mm} \mathrm{Hg}$ & $2.63 \mathrm{~mm} \mathrm{Hg}$ & 0.84 \\
\hline
\end{tabular}

Table 5: Clinical results of SLT with respect of amount of angle treated

\begin{tabular}{|c|c|c|c|c|c|}
\hline Author & Method of study & Number of eyes & $\begin{array}{l}\text { Degree of } \\
\text { angle treated }\end{array}$ & $\begin{array}{l}\text { Duration of } \\
\text { follow-up }\end{array}$ & Conclusion \\
\hline Prasad et $\mathrm{al}^{60}$ & $\begin{array}{l}\text { Retrospective } \\
\text { chart review }\end{array}$ & $\begin{array}{l}41 \text { ( } 19 \text { eyes in the } \\
180^{\circ} \mathrm{TM} \text {, } \\
22 \text { eyes in the } \\
\left.360^{\circ} \mathrm{TM}\right)\end{array}$ & $\begin{array}{l}180 \text { and } 360^{\circ} \\
\text { of TM }\end{array}$ & 2 years & $\begin{array}{l}360^{\circ} \mathrm{SLT} \text { is more } \\
\text { efficacious }\end{array}$ \\
\hline Chen et al ${ }^{43}$ & $\begin{array}{l}\text { Prospective } \\
\text { randomized trial }\end{array}$ & 64 & $\begin{array}{l}25 \text { laser spots on } \\
90^{\circ} \text { and } 50 \text { laser spots } \\
\text { on } 180^{\circ} \mathrm{TM}\end{array}$ & $\begin{array}{l}1,4 \text { and } 7 \text { months } \\
\text { after treatment }\end{array}$ & $\begin{array}{l}\text { Identical between the } \\
2 \text { groups }\end{array}$ \\
\hline Song et al ${ }^{59}$ & $\begin{array}{l}\text { Retrospective } \\
\text { chart review }\end{array}$ & 94 eyes & $\begin{array}{l}\text { A majority }(83 / 92,90 \%) \\
\text { underwent } \\
180^{\circ} \mathrm{SLT}\end{array}$ & 6 months & Failure rates of 68 to $74 \%$ \\
\hline Ayala et $a^{61}$ & $\begin{array}{l}\text { Retrospective chart } \\
\text { review }\end{array}$ & 120 eyes & & 18 months & $\begin{array}{l}\text { They recommend treating } \\
\text { patients over } 180^{\circ} \mathrm{TM}\end{array}$ \\
\hline
\end{tabular}

intraocular pressure fluctuation in patients with ocular hypertension and primary open angle glaucoma who received SLT as primary therapy without any subsequent medical or surgical intervention followed up for a period of 2 years. Forty-one eyes were treated by SLT, 19 eyes in the $180^{\circ}$ group and 22 eyes in the $360^{\circ}$ group. The mean reduction in IOP at 2 years was $28 \%$ in $180^{\circ}$ group and $35 \%$ in $360^{\circ}$ SLT group. After the SLT, the $360^{\circ}$ SLT group had a lower IOP fluctuation compared with the $180^{\circ}$ SLT group over the follow-up period of months 6 to 24 months. This study suggests that $360^{\circ}$ SLT is more efficacious in achieving smaller IOP fluctuations than treatment with $180^{\circ}$ SLT.

Ayala et $\mathrm{al}^{61}$ conducted a retrospective chart review of eyes that underwent SLT. The primary outcome measure was time to failure after SLT treatment, 120 eyes of 120 patients were identified. The average time to failure after SLT was 18 months. The success rate after 12 months was $62 \%$, after 24 months $34 \%$, after 36 months $28 \%$ and after 48 months $24 \%$. The long-term effects of SLT, when eyes were treated over $90^{\circ}$, seem to be low. They recommend treating patients over $180^{\circ}$.

The results of the main clinical evaluations are summarized in Table 5.

\section{SLT IN DIFFERENT SUBTYPES OF GLAUCOMA}

SLT is commonly used to treat patients with open angle glaucoma, (i.e. primary open-angle glaucoma, pigmentary glaucoma, exfoliative glaucoma). However, recent studies have examined the efficacy and safety of SLT to lower IOP in other glaucoma subtypes as well. Although limited by small sample sizes and lack of control groups, these studies suggest an expanding clinical role for LTP.

\section{SLT in PACG}

SLT seems to be a safe and effective method of reducing IOP in many eyes with primary angle closure and a patent iridotomy in which there is a sufficient extent of visible TM. Ho et $\mathrm{al}^{62}$ conducted a multicentric, prospective, noncontrolled clinical trial to determine, whether SLT can lower intraocular pressure in eyes with chronic primary angle closure, elevated IOP, and a patent iridotomy. Sixty eyes of 60 patients with chronic angle closure who had undergone iridotomy, had an IOP greater than $21 \mathrm{~mm} \mathrm{Hg}$ and a gonioscopically visible pigmented TM for at least $90^{\circ}$ were enrolled. SLT was applied to open angle segments. Patients were followed-up for 6 months. The mean baseline IOP was $24.6 \pm 2.5 \mathrm{~mm} \mathrm{Hg}$. At 6 months, IOP reduction of 
3 or $4 \mathrm{~mm} \mathrm{Hg}$ was measured in 82 and $72 \%$ of eyes respectively, and IOP reduction of 20 or $30 \%$ was measured in 54 and $24 \%$ of eyes respectively .There were no significant complications attributable to SLT.

\section{SLT in Steroid-induced Glaucoma}

Steroid-induced glaucoma has become common with the rise in usage of intravitreal steroids to treat a variety of posterior segment disorders. There have been very few studies to assess the efficacy of SLT in steroid-induced glaucoma. SLT is a temporizing procedure to consider in patients with steroid induced elevated IOP.

Rubin ${ }^{63}$ et al conducted a retrospective review to access effectiveness of SLT in lowering IOP in patients with steroid-induced elevated IOP of seven patients ( 7 eyes) with IOP elevation after intravitreal triamcinolone acetonide (IVTA; $4.0 \mathrm{mg} / 0.1 \mathrm{ml}$ ) injections for macular edema (6 patients) or central retinal vein occlusion (1 patient). SLT lowered $(p<0.007)$ IOP in five eyes of seven patients with steroid-induced increased IOP from 3 weeks to 6 months postoperative.

Ercument et $\mathrm{al}^{64}$ conducted a prospective, comparative, interventional case series to evaluate the prophylactic efficacy of SLT for preventing an increase in IOP after IVTA injection, they studied 31 eyes with a baseline IOP of 21 $\mathrm{mm} \mathrm{Hg}$ or more of 31 patients for which IVTA injection was planned for diabetic macular edema. The patients were divided into two groups. The study group comprised 15 eyes of 15 patients that underwent SLT a mean of $8.3 \pm 4.1$ days before IVTA injection. The control group comprised 16 eyes of 16 patients who underwent only IVTA injection. Main outcomes measures were mean IOP and number of patients requiring antiglaucoma therapy. They concluded that the IOP elevation after IVTA injection may be prevented by performing SLT before IVTA injection, especially in with a baseline IOP of $21 \mathrm{~mm} \mathrm{Hg}$ or more.

Pizzimenti et $\mathrm{al}^{65}$ reported a case of steroid glaucoma induced by IVTA in which IOP declined from $38 \mathrm{~mm} \mathrm{Hg}$ on maximal medical therapy to $16 \mathrm{~mm} \mathrm{Hg}$ on no topical therapy within 2 months after $180^{\circ}$ SLT.

\section{SLT in Pseudoexfoliative (XFG) Glaucoma}

Gracner et $\mathrm{al}^{66}$ demonstrated in a small prospective trial consisting of 10 eyes each with POAG and XFG glaucoma that $180^{\circ}$ SLT produced comparable IOP reductions in both groups. At 18 months, IOP was reduced by a mean of $35.1 \%$ in POAG eyes and $31.4 \%$ in XFG eyes.

Melamed et $\mathrm{al}^{67}$ included five eyes with XFG in which IOP was reduced by an average of $41 \%$; because the sample size was small, these authors did not attempt statistical comparison to the eyes with POAG.

Chen et $\mathrm{al}^{43}$ found that after 1 and 4 months, the presence of XFG had no effect on post-SLT IOP reduction, but was significantly more prevalent in eyes that did not have retreatment, suggesting an association with increased success rate after SLT. One subgroup analysis showed that 1 year after SLT, XFG glaucoma was not associated with a different outcome compared with OAG. These preliminary findings suggest that SLT is effective in eyes with XFG, with similar efficacy to eyes with OAG and similar efficacy to that of ALT.

\section{SLT in Normal Tension Glaucoma (NTG)}

El Mallah et $\mathrm{al}^{68}$ performed a retrospective study of SLT in 31 eyes of 18 patient diagnosed with NTG. The mean postoperative IOP was $12.2 \pm 1.7 \mathrm{~mm} \mathrm{Hg}$ from a baseline of $14.3 \pm 2.6 \mathrm{~mm} \mathrm{Hg}$. SLT-treated eyes also showed decreased IOP fluctuation of $2.5 \pm 1.9$ (during 1-year posttreatment) vs $4.5 \pm 2.5 \mathrm{~mm} \mathrm{Hg}$ (pretreatment).

\section{SLT in Heavily Pigmented TM}

There is some evidence showing a correlation between the degree of angle pigmentation and the effectiveness of SLT.

The study by Van de Veire et al $^{69}$ comparing SLT to ALT included two eyes with pigmentary glaucoma who received SLT; both eyes experienced a paradoxical $16 \%$ rise in IOP. The same investigators then performed SLT with lower energy $(<0.9 \mathrm{~mJ})$ in six more eyes with heavily pigmented angles and observed a $19 \%$ rise in IOP that persisted for 12 weeks.

Harasymowycz et $\mathrm{al}^{70}$ reported IOP spikes in four patients with heavily pigmented angles, with peak IOPs ranging from 31 to $65 \mathrm{~mm} \mathrm{Hg}$; three of the four subjects required trabeculectomy.

Melamed et $\mathrm{al}^{67}$ included three cases of pigmentary glaucoma; in these patients, SLT produced an intraocular pressure reduction in $24 \%$ of eyes.

Damji et $\mathrm{al}^{57}$ obtained an intraocular pressure reduction of $5.6 \mathrm{~mm} \mathrm{Hg}$ in five pigmentary glaucoma patients treated with SLT after 12 months.

\section{Adverse Effects of SLT}

In general adverse effect in SLT have been transient and minor. Early postoperative elevation of IOP in some patients has been observed in all published series, whether or not the patients were receiving perioperative antihypertensive treatment. IOP can spike in 3 to $5 \%$ of eyes, commonly occurring 1 to 4 hours after the procedure. 


\section{IOP Spikes}

Latina et $\mathrm{al}^{48}$ reported IOP spikes of $5 \mathrm{~mm} \mathrm{Hg}$ or greater in $25 \%$ of SLT-treated eyes and IOP spikes of $8 \mathrm{~mm} \mathrm{Hg}$ or greater in $9 \%$ of treated eyes. All manifested within 2 hours after treatment, resolved with IOP-lowering medications within 24 hours, and no eyes exhibited a persistent IOP elevation. Damji et $\mathrm{al}^{53}$ reported that $3.4 \%$ of ALT-treated eyes and $4.5 \%$ of SLT-treated eyes exhibited an IOP rise of $6 \mathrm{~mm} \mathrm{Hg}$ or greater within 1 hour after treatment. Nagar et $\mathrm{al}^{53}$ reported that $27 \%$ of eyes undergoing $360^{\circ}$ SLT manifested an IOP spike of $5 \mathrm{~mm} \mathrm{Hg}$ or more (compared with no IOP spikes in latanoprost-treated eyes). Lai et $\mathrm{al}^{51}$ reported that $10.3 \%$ of $360^{\circ}$ SLT-treated eyes manifested an IOP spike of $5 \mathrm{~mm} \mathrm{Hg}$ or greater.

\section{Anterior Chamber Inflammation}

In the study of $180^{\circ}$ SLT by Latina et al, ${ }^{48} 83 \%$ of SLTtreated eyes exhibited mild-to-moderate inflammation, appearing within 1 hour after treatment, decreasing by 24 hours after treatment, and completely resolved in all cases within 5 days of treatment. Martinez-de-la-Casa et $\mathrm{al}^{55}$ evaluated flare using the Kowa flare meter and found significantly lower flare readings after SLT than ALT. Damji et $\mathrm{al}^{53}$ reported more anterior chamber inflammation in the first 1 hour after SLT than ALT. Nagar et al ${ }^{50}$ reported a 50\% rate of anterior chamber inflammation in eyes receiving $360^{\circ}$ SLT vs $0 \%$ in latanoprost-treated eyes. A single case report of hyphema after SLT has also been reported.

\section{Ocular Discomfort}

Latina et $\mathrm{al}^{48}$ reported that $15 \%$ of eyes receiving SLT reported discomfort after the procedure. Martinez-de-la-Casa et $\mathrm{al}^{55}$ evaluated postoperative pain using a 10-point scale and found significantly lower pain scores after SLT compared with ALT during and immediately after treatment; these differences were gone by 24 hours posttreatment. Nagar et $\mathrm{al}^{50}$ reported a $39 \%$ rate of discomfort in eyes undergoing $360^{\circ} \mathrm{SLT}$ and a $0 \%$ rate in eyes receiving latanoprost.

\section{Repeat Selective Laser Trabeculoplasty}

SLT is becoming an increasingly popular alternative to ALT in the treatment of open-angle forms of glaucoma, primarily owing to the lack of collateral thermal damage and TM scarring with SLT as compared with ALT. Since SLT delivers only one tenth of the energy compare with ALT and it causes minimal thermal damage to TM it has a greater potential of repeatability. Since its approval, there have been very few studies to study the efficacy of repeatability of SLT despite of strong theoretical proof for it. Bryan Kun Hong et $\mathrm{al}^{71}$ conducted a retrospective chart review of forty-four eyes of 35 patients, underwent an initial $360^{\circ}$ SLT (SLT1), which was successful for 6 months, but eventually lost efficacy and was followed by a repeat $360^{\circ}$ SLT (SLT2). Using a definition of 'success' as $>20 \%$ peak IOP reduction, success rates for SLT1 and SLT2 were not significantly different. They concluded that repeat $360^{\circ}$ SLT may be safe and effective after an initially successful $360^{\circ}$ SLT has failed.

\section{Comparative Analysis of Cost of Medical Man- agement with SLT}

There has been many studies to prove that the common cause of failure of medical management in glaucoma is lack of compliance. Nordstorm et $\mathrm{al}^{72}$ did a retrospective cohort study using health insurance claims data of newly treated individuals with diagnosed glaucoma $(n=3623)$ and suspect glaucoma $(n=1677)$, and concluded that many patients fail to use topical medications as prescribed. Nearly one half of the individuals who had filled a glaucoma prescription discontinued all topical ocular hypotensive therapy within 6 months, and just $37 \%$ of these individuals recently had refilled their initial medication at 3 years after the first dispensing. The other cause of failure of reported is cost of glaucoma medication.

Centaur et $\mathrm{al}^{73}$ compared the 5-year costs of three treatment strategies: medication, LTP, and filtering surgeries in managing patients with primary open-angle glaucoma whose intraocular pressures were not adequately controlled by two medication. The 5-year cumulative costs were approximately $\$ 6571, \$ 4838$ and $\$ 6363$ for patients in the medication, LTP and filtering surgery arms respectively. Over 5 years, LTP was associated with the lowest total costs compared to treatment by medication alone or by filtering surgery for patients who were not adequately controlled by two medications.

Lee et $\mathrm{a}{ }^{10}$ presented a projected 6 -year cost comparison of primary SLT versus primary medical therapy in the treatment of open-angle glaucoma for patients aged 65 years or more their findings suggest that SLT as primary therapy, at a per-patient level, offers a modest potential cost saving over primary medical therapy in the management of openangle glaucoma for patients aged 65 years or more. In the SLT rep 2y scenario, the use of primary SLT over mono-, bi-, and tri drug therapy produced a 6-year cumulative cost savings of 206.54 dollars, 1668.64 dollars, and 2992.67 dollars per patient respectively.

\section{CONCLUSION}

SLT is increasingly being used in clinical practice as both, the primary procedure and as an adjunct to medical and 
surgical therapy. Preliminary published evidence suggests that SLT is a effective, compliance-free, repeatable and safe therapeutic modality having only minor, transient, selflimiting or easily controlled side effects with no sequelae. Also, the use of SLT has a better quality of life impact than medication or surgery. Its use has been found to be costsaving, thereby reducing the economic burden of the disease.

However, the response rates within the first postoperative year have varied from 59 to $96 \%$, according to different definitions. The reported average reduction in IOP from pretreatment IOP ranges from 18 to $40 \%$, over a follow-up period of 6 to 12 months, with some authors reporting results for the whole cohort and others only for responders. Therefore, it must be emphasized that SLT is not a cure, and all patients must remain under regular follow-up.

\section{REFERENCES}

1. Sommer A, Tielsch JM, Katz J, Quigley HA, Gottsch JD, Javitt JC, Martone JF, Royall RM, Witt KA, Ezrine S. Racial differences in the cause specific prevalence of blindness in east Baltimore. N Engl J Med 1991 Nov;325(20):1412-1417.

2. Worthen DM, Wickham MG. Argon laser trabeculotomy. Trans Am Acad Ophthalmol Otolaryngol 1974 MarApr;78(2):OP371-75.

3. Krasnov MM. Laseropuncture of anterior chamber angle in glaucoma. Am J Ophthalmol 1973 Apr;75(4):674-678.

4. Wise JB, Witter SL. Argon laser therapy for open-angle glaucoma: A pilot study. Arch Ophthalmol 1979 Feb;97(2):319322.

5. Spurny RC, Lederer CM Jr. Krypton laser trabeculoplasty. A clinical report. Arch Ophthalmol 1984 Nov;102(11):1626-1628.

6. Belgrado, G.; Brihaye-Van, GM, Herzeel R. Comparison of argon and CW Nd: YAG laser trabeculoplasty, Clinical results. In: Marshall J, editor. Laser technology in ophthalmology. Berkeley: Amsterdam; Kugler \& Ghedini; Berkeley, CA: Distributor for the USA and Canada, Kugler Publications; 1988. pp.45-52.

7. McHugh D, Marshall J, Ffytche TJ, Hamilton PA, Raven A. Diode laser trabeculoplasty (DLT) for primary open-angle glaucoma and ocular hypertension. Br J Ophthalmol 1990 Dec;74(12):743-747.

8. The glaucoma laser trial research group. The glaucoma laser trial (GLT). 2. Results of argon laser trabeculoplasty versus topical medicines. Ophthalmology 1990 Nov;97(11):1403-1413.

9. The glaucoma laser trial research group. The glaucoma laser trial (GLT) and glaucoma laser trial follow-up study: 7. Results. Am J Ophthalmol 1995 Dec;120(6):718-731.

10. Lee R, Hutnik CM. Projected cost comparison of selective laser trabeculoplasty versus glaucoma medication in the Ontario Health Insurance Plan. Can J Ophthalmol 2006 Aug;41(4): 449-456

11. Lee MD, Fechtner FR, Fiscella RG, Singh K, Stewart WC. Emerging perspectives on glaucoma: Highlights of a roundtable discussion. Am J Ophthalmol 2000 Oct;130(4 Suppl):S1-S11.

12. Nordstrom BL, Friedman DS, Mozaffari E, Quigley HA, Walker AM. Persistence and adherence with topical glaucoma therapy. Am J Ophthalmol 2005 Oct;140(4):598-606.
13. Olthoff CM, Schouten JS, van de Borne BW, Webers CA. Noncompliance with ocular hypotensive treatment in patients with glaucoma or ocular hypertension an evidence-based review. Ophthalmology 2005 Jun;112(6):953-961.

14. Stewart WC, Konstas AG, Pfeiffer N. Patient and ophthalmologist attitudes concerning compliance and dosing in glaucoma treatment. J Ocul Pharmacol Ther 2004 Dec;20(6):461-469.

15. Nelson WL, Fraunfelder FT, Sills JM, Arrowsmith JB, Kuritsky $\mathrm{JN}$. Adverse respiratory and cardiovascular events attributed to timolol ophthalmic solution, 1978-1985. Am J Ophthalmol 1986 Nov;102(5):606-611.

16. Osborne SA, Montgomery DM, Morris D, McKay IC. Alphagan allergy may increase the propensity for multiple eye-drop allergy. Eye (Lond) 2005 Feb;19(2):129-137.

17. Noecker RJ, Herrygers LA, Anwaruddin R. Corneal and conjunctival changes caused by commonly used glaucoma medications. Cornea 2004 Jul;23(5):490-496.

18. Broadway DC, Grierson I, O'Brien C, Hitchings RA. Adverse effects of topical antiglaucoma medication. The conjunctival cell profile. Arch Ophthalmol 1994 Nov;112:1437-45.

19. Broadway DC, Grierson I, O'Brien C, Hitchings RA. Adverse effects of topical antiglaucoma medication. II. The outcome of filtration surgery. Arch Ophthalmol 1994;112(11):1446-1454.

20. Chiba T, Kashiwagi K, Ishijima K, Furuichi M, Kogure S, Abe K, Chiba N, Tsukahara S. A prospective study of iridial pigmentation and eyelash changes due to ophthalmic treatment with latanoprost. Jpn J Ophthalmol 2004 MarApr;48(2):141-147.

21. Anderson RR, Parish JA. Selective photothermolysis: Precise microsurgery by selective absorption of pulsed radiation. Science 1983 Apr;220(4596):524-527.

22. van der Zypen E, Fankhauser F, England C, Kwasniewska S. Morphology of the trabecular meshwork within monkey (Macaca speciosa) eyes after irradiation with the free-running Nd: YAG laser. Ophthalmology $1987 \mathrm{Feb} ; 94(2): 171-179$.

23. Latina MA, Park C. Selective targeting of trabecular meshwork cells: In vitro studies of pulsed and CW laser interactions. Exp Eye Res 1995 Apr;60(4):359-371.

24. Rodriguez MM, Spaeth GL, Donohoo P. Electron microscopy of argon laser therapy in phakik open angle glaucoma. Ophthalmology 1982 Mar;89(3):198-210.

25. Anderson RR, Margolis RJ, Watenabe S, Flotte T, Hruza GJ, Dover JS. Selective photothermolysis of cutaneous pigmentation by Q-switched Nd:YAG laser pulses at 1064, 532, and $355 \mathrm{~nm}$. J Invest Dermatol 1989 Jul;93(1):28-32.

26. Parrish JA, Deustch TF. Laser photomedicine. IEEE J Quantum Electron 1984;12:1386-1396.

27. Mchugh D, Marshall J, Ffytche TJ, Hamilton PA, Raven A. Ultrastructural changes of human trabecular meshwork after photocoagulation with a diode laser. Invest Ophthalmol Vis Sci 1992 Aug;33(9):2664-2671.

28. Lin CP, Kelly MW, Sibayan SA, Latina MA. Selective cell killing by microparticle absorption of pulsed laser radiation. IEEE J Select Topics Quant Electron 1999 Jul-Aug;5(4):963-968.

29. Sherwood KA, Murray S, Kurban AK, Tan OT. Effect of wavelength on cutaneous pigment using pulsed irradiation. J Invest Dermatol 1989 May;92(5):717-720.

30. Van Buskirk EM. Pathophysiology of laser trabeculoplasty. Surv Ophthalmol 1989 Jan-Feb;33(4):264-272.

31. Byslma SS, Samples JR, Acott TS, Van Buskirk EM. Trabecular cell division following argon laser trabeculoplasty. Arch Ophthalmol 1988 Apr;106(4):544-547. 
32. Byslma SS, Samples JR, Acott TS, Van Buskirk EM. Repopulation of the trabecular meshwork after argon laser trabeculoplasty. Invest Ophthalmol Vis Sci 1988;29 (Suppl):129.

33. Gard TL, Acott TS, Van Buskirk EM. Proteoglycans and flow resistance in model of the trabecular meshwork. Invest Ophthalmol Vis Sci 1987;28(Suppl):130.

34. Knepper PA, Farbman AI, Telser AG. Aqueous outflow pathway glycosaminoglycans. Exp Eye Res 1981 Mar;32(3):265-277.

35. Van Buskirk EM, Pond V, Rosenquist RC, Acott TS. Argon laser trabeculoplasty studies of mechanism of action. Ophthalmology 1984 Sep;91(9):1005-1010.

36. Melamed S, Pei J, Epstein DL. Short-term effect of argon laser trabeculoplasty in monkeys. Arch Ophthalmol 1985 Oct;103(10):1546-1552.

37. Gracner T, Naji M, Hudovernik M, Gracner B, Pahor D. Predictive factors of successful selective laser trabeculoplasty in open-angle glaucoma. Klin Monbl Augenheilkd 2007 Dec; 224(12):922-926. (Ger).

38. Hodge WG, Damji KF, Rock W, Buhrmann R, Bovell AM, Pan Y. Baseline IOP predicts selective laser trabeculoplasty success at 1 year Posttreatment: Results from a randomized clinical trial. Br J Ophthalmol 2005 Sep;89(9):1157-1160.

39. Mao AJ, Pan XJ, McIlraith I, Strasfeld M, Colev G, Hutnik C. Development of a prediction rule to estimate the probability of acceptable intraocular pressure reduction after selective laser trabeculoplasty in open-angle glaucoma and ocular hypertension. J Glaucoma 2008 Sep;17(6):449-454.

40. Ayala M, Chen E. Predictive factors of success in selective laser trabeculoplasty (SLT) treatment. Clin Ophthalmol 2011;5:573576.

41. Latina MA, Sibayan SA, Shin DH, Noecker RJ, Marcellino G. Q-switched 532-nm Nd:YAG laser trabeculoplasty (selective laser trabeculoplasty):

A multicenter, pilot, clinical study. Ophthalmology 1998 Nov;105(11):2082-2090.

42. Lanzetta P, Menchini U, Virgili G. Immediate intraocular pressure response to selective laser trabeculoplasty. $\mathrm{Br} \mathrm{J}$ Ophthalmol 1999 Jan;83(1):29-32.

43. Chen E, Golchin S, Blomdahl S. A comparison between 90 degrees and 180 degrees selective laser trabeculoplasty. J Glaucoma 2004 Feb;13(1):62-65.

44. Johnson PB, Katz LJ, Rhee DJ. Selective laser trabeculoplasty: Predictive value of early intraocular pressure measurements for success at 3 months. Br J Ophthalmol 2006 Jun;90(6):741-743.

45. Cvenkel B. One-year follow-up of selective laser trabeculoplasty. In open-angle glaucoma. Ophthalmologica 2004 JanFeb;218(1):20-25.

46. Gracner T. Intraocular pressure response to selective laser trabeculoplasty in the treatment of primary open-angle glaucoma. Ophthalmologica 2001 Jul-Aug;215(4):267-270.

47. Kajiya S, Hayakawa K, Sawaguchi S. Clinical results of selective laser trabeculoplasty. Jpn J Ophthalmol 2000 Sep;44(5):574-575.

48. Hodge WG, Damji KF, Rock W, Buhrmann R, Bovell AM, Pan Y. Baseline IOP predicts selective laser trabeculoplasty success at 1 year posttreatment: Results from a randomised clinical trial. Br J Ophthalmol 2005 Sep;89(9):1157-1160.

49. Katz LJ, Steinmann WC, Kabir A, Molineaux J, Wizov SS, Marcellino G; SLT/Med Study Group. Selective laser trabeculoplasty versus medical therapy as initial treatment of glaucoma: A prospective, randomized trial. J Glaucoma 2012 Sep;21(7):460-468.
50. Nagar M, Ogunyomade A, O'Brart DP, Howes F, Marshall J. A randomized prospective study comparing selective laser trabeculoplasty with latanoprost for the control of intraocular pressure in ocular hypertension and open angle glaucoma. Br J Ophthalmol 2005 Nov; 89(11):1413-1417.

51. Lai JS, Chua JK, Tham CC, Lam DS. Five-year follow-up of selective laser trabeculoplasty in Chinese eyes. Clin Experiment Ophthalmol 2004 Aug;32(4):368-372.

52. McIlraith I, Strasfeld M, Colev G, Hutnik CM. Selective laser trabeculoplasty as initial and adjunctive treatment for open-angle glaucoma. J Glaucoma 2006 Apr;15(2):124-130.

53. Damji KF, Shah KC, Rock WJ, Bains HS, Hodge WG. Selective laser trabeculoplasty V Argon laser trabeculoplasty: A prospective randomised clinical trial. Br J Ophthalmol 1999 Jun;83(6):718-722.

54. Juzych MS, Chopra V, Banitt MR, Hughes BA, Kim C, Goulas MT, Shin DH. Comparison of long-term outcomes of selective laser trabeculoplasty versus argon laser trabeculoplasty in openangle glaucoma. Ophthalmology 2004 Oct;111(10):1853-1859.

55. Martinez-de-la-Casa JM, Garcia-Feijoo J, Castillo A, Matilla M, Macias JM, Benitez-del-Castillo JM, Garcia-Sanchez J. Selective vs argon laser trabeculoplasty: Hypotensive efficacy, anterior chamber inflammation and postoperative pain. Eye (Lond) 2004 May;18(5):498-502.

56. Damji KF, Bovell AM, Hodge WG, Rock W, Shah K, Buhrmann R, Pan YI. Selective laser trabeculoplasty versus argon laser trabeculoplasty: Results from a 1-year randomised clinical trial. Br J Ophthalmol 2006 Dec;90(12):1490-1494.

57. Best UP, Domack H, Schmidt V. Pressure reduction after selective laser trabeculoplasty with two different laser systems and after argon laser trabeculoplasty - a controlled prospective clinical trial on 284 eyes. Klin Monatsbl Augenheilkd 2007 Mar;224(3):173-179. (Ger).

58. Popiela G, Muzyka M, Szelepin L, et al. Use of YAG-Selecta laser and argon laser in the treatment of open angle glaucoma. Klin Oczna 2000;102(2):129-133.

59. Song J, Lee PP, Epstein DL, Stinnett SS, Herndon LW Jr, Asrani SG, Allingham RR, Challa P. High failure rate associated with 180 degrees selective laser trabeculoplasty. J Glaucoma 2005 Oct;14(5):400-408.

60. Prasad N, Murthy S, Dagianis JJ, Latina MA. A comparison of the intervisit intraocular pressure fluctuation after 180 and 360 degrees of selective laser trabeculoplasty (SLT) as a primary therapy in primary open angle glaucoma and ocular hypertension. J Glaucoma 2009 Feb;18(2):157-160.

61. Ayala M, Chen E. Long-term outcomes of selective laser trabeculoplasty (SLT) treatment. Open Ophthalmol J 2011;5:3234.

62. Ho CL, Lai JS, Aquino MV, Rojanapongpun P, Wong HT, Aquino MC, Gerber Y, Belkin M, Barkana Y. Selective laser trabeculoplasty for primary angle closure with persistently elevated intraocular pressure after iridotomy. J Glaucoma 2009 Sep;18(7):563-566.

63. Rubin B, Taglienti A, Rothman RF, Marcus CH, Serle JB. The effect of selective laser trabeculoplasty on intraocular pressure in patients with intravitreal steroid-induced elevated intraocular pressure. J Glaucoma 2008 Jun-Jul;17(4):287-292.

64. Bozkurt E, Kara N, Yazici AT, Yuksel K, Demirok A, Yilmaz OF, Demir S. Prophylactic selective laser trabeculoplasty in the prevention of intraocular pressure elevation after intravitreal triamcinolone acetonide injection. A J Ophthalmol 2011 Dec;152(6):976-981. 
65. Pizzimenti JJ, Nickerson MM, Pizzimenti CE, Kasten-Aker AG. Selective laser trabeculoplasty for intraocular pressure elevation after intravitreal triamcinolone acetonide injection. Optom Vis Sci 2006 Jul;83(7):421-425.

66. Gracner T. Intraocular pressure response of capsular glaucoma and primary openangle glaucoma to selective Nd: YAG laser trabeculoplasty: A prospective, comparative clinical trial. Eur J Ophthalmol 2002 Jul-Aug;12(4):287-292.

67. Melamed S, Ben Simon GJ, Levkovitch-Verbin H. Selective laser trabeculoplasty as primary treatment for open-angle glaucoma: A prospective, nonrandomized pilot study. Arch Ophthalmol 2003 Jul;121(7):957-960.

68. El Mallah MK, Walsh MM, Stinnett SS, Asrani SG. Selective laser trabeculoplasty reduces mean IOP and IOP variation in normal tension glaucoma patients. Clin Ophthalmol 2010 Aug;4:889-893.

69. Van de Veire S, Zeyen T, Stalmans I. Argon versus selective laser trabeculoplasty. Bull Soc Belge Ophtalmol 2006;299:5-10.

70. Harasymowycz PJ, Papamatheakis DG, Latina M, De Leon M, Lesk MR, Damji KF. Selective laser trabeculoplasty (SLT) complicated by intraocular pressure elevation in eyes with heavily pigmented trabecular meshworks. Am J Ophthalmol 2005 Jun;139(6):1110-1113.

71. Hong BK, Winer JC, Martone JF, Wand M, Altman B, Shields B. Repeat selective laser trabeculoplasty. J Glaucoma 2009 Mar;18(3):180-183.

72. Nordstrom BL, Friedman DS, Mozaffari E, Quigley HA, Walker AM. Persistence and adherence with topical glaucoma therapy. Am J Ophthalmol 2005 Oct;140(4):598-606.

73. Cantor LB, Katz LZ, Cheng JW, Chen E, Tong KB, Peabody JW. Economic evaluation of medication, laser trabeculoplasty and filtering surgeries in treating patients with glaucoma in the US. Curr Med Res Opin 2008 Oct; 24(10):2905-2918.

${ }^{1,3-5} \mathrm{Dr}$ RP Centre for Ophthalmic Sciences, All India Institute of Medical Sciences, New Delhi, India

${ }^{2}$ Consultant, Glaucoma Services, Eye 7 Group of Hospitals, New Delhi India

Corresponding Author: Bhaskar Jha, Dr RP Centre for Ophthalmic Sciences, All India Institute of Medical Sciences, New Delhi, India, e-mail: drbhaskarjha@gmail.com 